\title{
Continuum Concept of Motivation Factors and Discipline of Employees to Improve Quality of Service
}

\author{
M Siswoyo ${ }^{1}$, E Susilawati $^{2}$ \\ \{muksis2000@ gmail.com ${ }^{1}$ \} \\ ${ }^{1,2}$ Administrasin Science at University of Swadaya Gunung Jati, Cirebon, West Java, \\ Indonesia
}

\begin{abstract}
To improve the motivation of employees to work, it needs to give the reward objectively, such as giving a reward for the best employees. This reward can be increasing the incentive, bonus, praise, or the best employee achievement. The leader needs to improve a personal approach to the employee to accommodate the aspirations' or complaints' of the employees related to their job. Giving employees attention is a kind of motivation for them. So they are motivated to work. To improve employee discipline, it needs to implement a fair punishment system for those who are undisciplined in the work through persuasive approach. It is hoped that it can raise their self-awareness to work with discipline. That mecanism concept can lead to improving the quality of service to society.
\end{abstract}

Keywords: Motivation, Employee Discipline, Service Quality.

\section{Introduction}

The implementation of good governance is the most prominent issue in the management of public administration in the Republic of Indonesia. This is influenced by the public demand to the government to conduct good governance and it is in line with the increase of community dynamics and knowledge of society. The government in this case as civil servant functioned as the servant of society. It must give the best service to society because giving service to society is the function of the civil servant.

Discipline factors play an important role in implementing the best service to the society. The employees who have high level of discipline will work well though they are not supervised by the boss. The discipline employees will not be doing anything in their job. And the employee will obey the roles in the work environment with the awareness or without coercion. In the end, the employees who have a high level of discipline will have high quality of work and it will influence to give the best service to the society because they do the job as the target to reach.

Motivation factors also play an important role to improve the quality service to the society. Motivation is as a trigger to do the activity to get the best result. It cannot be denied that the employee with high motivation has high qualification in the work. So that the employees' motivation must be awakened in order to they work well and give the best service to the society. The problem is that un optimal service still can be found in the government institution. It can be influenced by the low discipline and motivation of employees. Thus a question 
comes up "how do the discipline employees influence the quality service in the government instantiation?"

\section{Method}

In order to get the data for this paper, the research is done using a qualitative approach. Qualitative research is a method to explore and understand the meaning ---that by some individuals and groups is considered coming from social or humanity problems [1]. The data in this research is collected from literature study by learning various relevant literature, in the form of books, rules of law, or data from internet.

\section{Result and Discussion}

\subsection{Organization Culture Concept}

Through etymological, motivation comes from movere (Latin) and it has similar meaning with to move (English) with the meaning to push or to move. Motivation is as an effort to raise individual spirit, the spirit of employee to work in order to reach the goal by giving their needs.

Motivation arises because of the motive from the person as proposed by Ali 2005: 756, he said that the meaning of motivation as follows:

The impulses come from someone consciously or unconsciously to act an action with a certain purpose or the efforts cause someone or group to do something because they want to achieve the goal or get satisfaction from their actions.

Every motive has a certain goal to be achieved as Siagian[2] said:

Motive is a psychological circumstance that encourages to activate or to move. Motive aims the behavior, attitude of people. A motive is also associated with achieving the goal, both organizational goals, and personal goals.

Motivation is the result of a person's interaction with a particular situation. According to motivation is a willingness to create high levels of effort for organizational goals which is adjusted by the ability to full fill the needs.

According to Ranupandjoyo, Heidjrahman and Husnan [3], the theory of motivation can be grouped into two categories: content theories that focus on the attention of the factors of people that energize, direct, sustain, and stop. Process theories that describe and analyze how the behavior is reinforced, directed, supported and discontinued.

According to Ranupandjoyo, Heidjrahman, and Husnan [3], kinds of motivation can be grouped into two categories, those are:

a. Positive motivation is a process to influence others to do something that we want with the way such as giving the reward.

b. Negative motivation is a process to influence others to do something that we want, but the basic technique used is through the power of anxiety. The knowledge of human motivation is still developing, it deals with the human motivation that is dynamic. Meaning that motivation follows the development of human and environment. Basically, motivation is influenced by the perception of people that develop their age, life, social, culture, environment, organization, or the place that they work. The motivation that arises from employees, executives, and the leader of labor has similarities and differences.

Mc. Clelland in Hasibuan [4] stated his theory which is called Mc Clelland's Achievement Motivation Theory. The points which motivate people are a The need for achievement, $\mathrm{b}$ The need for affiliation, $\mathrm{c}$. The need for power

The explanations are as follows: 
a. The need for achievement

The need for achievement is a trigger that motivates people's spirit to work because this need will encourage someone to develop their creativities and aim all skills and energies to achieve the job performance. The employees will be enthusiastic to work well if they are given the opportunity. The need of achievement reflects from their desire to take responsibility in doing a job given. They decide the goals and also count the risk from the job. They get feedback from their attitude and they try to do everything with creative and innovative. They realize that they will get high income if they work well. By the high income, they can fill their needs.

b. The need for affiliation as a trigger that motivates people's spirit to work

This is shown by the desire to associate where they emphasize on their work, they are happy to cooperate, they ask other opinions to get the agreement form the others, and they do their job more effective if they cooperate with others in cooperation. Thus, this need attracts the spirit of employees to work because everyone wants things as follows:1) Sense of belonging, 2) Sense of important, 3) Sense of achievement, 4) Sense of participation.

c. The need for power

The need for power is a trigger that motivates people's spirit to work. This need reflects on someone who has influence over others, sensitivity to influence structure among groups or organizations, entering the organization that has the achievement, obeying the policy of the organization, trying to lead others by managing them and make them impressed, and keeping the reputation and leadership. Thus, this need will attract and motivate the spirit of employees to work and they are all out with their capabilities in order to achieve the power and good position.

Efforts to optimize the achievement of organizational goals through the provision of motivation must be really considered. We need to note about the process of giving good motivation as presented by Hasibuan [4] as follows:

1) The goals in the process of motivation must be set earlier than organizational goals. Then the employees are motivated to achieve those goals.

2) Knowing the interest; in the process of motivation, it is important to know the need of employees and it is not seen only by the interest of the leader and the company.

3) Effective communication; effective communication with employees must be conducted in the process of motivation. The employees have to know what they will get with some conditions such as what they must do to get the incentive.

4) Integrated goals; the goals of the factory and the employees must be united in the process of motivation. The goal of the company needs complex such as to get the profit, company expansion. And the goal of employees is to fulfill their needs. So the need of the company and employees must be united.

5) Facilities; in the motivation, the manager have to facilitate the company and employees that are able to support their work.

6) Teamwork; the manager has to create the teamwork that can coordinate well to achieve the company's goals because there are many subs in the company.

The main problem in the motivation is how to make the employees work optimally to achieve the organizational goals. Maslow in Hasibuan [4] has developed a concept of the motivational theory known as the hierarchy of needs as follows:

1) Physiological Needs

The implementation of physiological need is the need of human being such as clothes, house, food, and individual prosperity. These needs are categorized as basic needs because people cannot live normally without those needs. 
2) Safety Needs

Safety need must be seen from wide perspectives. It is not only in the meaning of physical safety but also physiological safety, and the equal treatment in the job.

3) Social Needs

Human beings are social creatures. They cannot fulfill their need by themselves, and they need the assistance of others. So they must get along to others.

4) Esteem Needs

Everyone needs acknowledgment or status from other people. The ideal situation is when the prestige appears and it makes someone get the achievement. But, if someone gets a higher position, there will be many symbols used.

5) Self Actualization

Everyone has the talent to develop, then it can be a contribution to the organization. The ability to work well will influence/fulfill their needs. Someone tends to develop himself to do best.

Basically, organization or company hope that the employees not only have an ability, capability, and skill but also they can work well to achieve the goals optimally. The ability, capability, and skill are meaningless if the employees don't want to work hard by using those abilities, capabilities, and skills.

Motivation is important because the employees are hoped to work hard and be enthusiastic to achieve the quality of job performance. But it must be realized that they want to work hard because they want to fulfill their needs from the work.

\subsection{Understanding Work Discipline in Conceptual Level}

Discipline is the attitude of life that reflects responsibility. This attitude or behavior is followed because that is true and beneficial for them and society. Etymologically, discipline comes from the Latin "disipel" which means followers. By the development of the era, the word is changed to "disipline" which means pursuance that relates with the order. Meanwhile, according to Hasibuan [4], discipline is the awareness and adherence of a person to the rules of the company/institution and social norms that prevail.

According to The Liang Gie [5], discipline is defined as the order in which people in the organization obey the rules gladly. Meanwhile, according to Wursanto [6], the discipline of work is an attitude of obedience of a person to the rules/provisions that is applied in the organization or joining the organization with awareness or without coercion. Based on these opinions, the discipline of work is an attitude of obedience to the organizational rules of the organization.

According to Siagian [2], work discipline is a mental attitude that is reflected in the actions or behavior of a person, society in the form of obedience to the rules, norms prevailing in society. So discipline is a mental attitude that is reflected in the actions or behavior of a person, society in the form of obedience to the rules, norms prevailing in society.

According to Terry [7], kinds of work discipline are:

a. Self-discipline

This discipline arises because people feel that their needs are fulfilled and become part of the organization, so they will obey the rules consciously.

b. Command discipline

This discipline grows not from feelings of sincerity but arises from the coercion of others. In every organization, the first kind of organization is needed. But the fact always shows that 
discipline is mostly caused by coercion of others. Discipline refers to behavioral patterns with the following characteristics:

1) There is a strong desire to fully implement what has become the norm, ethics, applicable norms.

2) Controlled behavior.

3) The obedience.

The discipline or undisciplined of employees can be seen from:

1) The obedience of employees to the rules such as they come on time and have a responsibility with their job.

2) Using the procedures to work.

3) Keeping the facilities of the office.

According to Handoko [8], there are three types of discipline activities. Those are:

1) Preventive discipline: the activity that encourages employees to follow various standards and rules, so the deviation can be prevented. The main purpose of this activity is to encourage self-discipline among employees. The employee can work consciously without any coercion.

2) Corrective discipline: an activity undertaken to deal with violations committed by employees through regulations and to prevent further violations. The corrective activity can be in the form of punishment, for instance, giving suspension to the employees.

3) Progressive discipline: an activity to give heavy punishment to the repeated violation. The examples of progressive discipline are:

a) Verbal warning from the supervisor.

b) Written warning.

c) Suspension from work for several days.

d) Demoting the position

e) Being fired.

Although the order exists, the employees don't obey the rules by themselves but it needs the assistance of organization to manage the employee to obey the rules. To manage the employee to be discipline, some principles of discipline are proposed as follows:

a. Discipline is done personally.

a. Discipline is done by avoiding not to reprimand in front of people, because it can make the employee shame and anger.

b. Constructive discipline

a. Besides showing the mistakes of the employees, it is necessary to give away to solve them. So the employee is not confused to face the mistakes done by themselves. In doing the discipline to employees, equal treatment is needed without differentiating the employees.

c. The discipline is done when the employees are not absent

a. The leader should do the discipline when the employees who made the mistake are present, so the employees will know that they made a mistake.

According to Hasibuan [4], indicators that influence the level of employee discipline are:

1) Goals and abilities

2) Leader's example

3) Recompensation

4) Justice

5) Intensive supervising

6) Punishment

7) Firmness

8) Humanitarian relations 
Based on those opinions, it can be concluded that work discipline is the attitude of obedience from a person or people to the written or not written rules which reflect in the behavior at an organization to achieve certain goals. The purpose of both collective and individual discipline is to direct behavior to a harmonious reality. To create these conditions, harmony must be created between the rights and obligations of employees.

The main purpose of discipline is to encourage employees to have good behavior in the place where they work. The behavior is set as regulations or procedures that is functioned as law in the society. Discipline is one of functions from the management or human resource as the important operational function of MSDM. Because if the employees work well, they will achieve their goals. Without the discipline of the employees, it is difficult for organization to achieve the optimal result.

\subsection{Quality of Service}

The implementation of government is based on a new paradigm, that is as a servant of society not being served by society, it is based on Good Governance. It is in line with the opinion of Widodo [9], he said that:

Essentially, the government is a servant of society, not to serve itself but to serve society and create the condition that allows the society to develop the skill and creativity to achieve the goal together.

According to Kotler [10] the definition of service is any activities that can be offered by a party to another party, which basically does not result in any ownership. The production can be linked or cannot be linked to a single physical product. Service is the behavior of producer in order to meet the needs and desires of consumers for the achievement of satisfaction on the consumer. In addition, Kotler also said that behavior can occur during, before and after the transaction. Generally high-quality services will result in high satisfaction and frequently repurchase. The word quality has a lot of definitions and meanings. Different people will define differently, but from the definitions we can find, it has similarities although it deals with the way to deliver. There are some elements as follows:

a. Quality covers the effort to fulfill the hope of the customer.

b. Quality covers product, service, human, process, and environment.

c. Quality is a condition that always changes.

Tjiptono[11] stated the quality is as a standard to be achieved by person/group/institution/organization on the quality of human resources, quality of work, process, a result of work, or the product such as goods and services. Quality has a meaning to satisfy the customer, both internal and external, in the meaning of fulfilling the needs of society optimally.

Based on the explanation above, it can be concluded that the quality of service is one of the answers of individuals, groups, and organizations public-private in addressing the era of competition with the emphasis aspect to fulfill the expectations of service users/customers. Quality service is a service that can fulfill customer expectation, or even more.

Basically, a quality which related to the service is an attitude of employees in serving the costumers or society. Luthans in Moenir [12] stated that service is a process of fulfilling the needs through activities of others to achieve the goals.

Quality of service has almost become a decisive factor in deciding the sustainability of a government bureaucratic organization or corporate organization. Good service which needs government service is very important to realize customer satisfaction society. Thus, this quality must be adjusted with product specifications demanded by customers, although 
actually it is difficult to decide whether the product has a quality or not. But the obligation of the provider of a service is to avoid any complaints from customers. As it is said by Lukman [13]:

"For customers, the quality of service is to adjust to the specifications demanded by customers. The customer decides how the quality is and if this value is. The customer considers the quality of service. The quality can be detected by its form so that it can be found: 1 the quality of service is a promise, 2 the quality is the achievement of an expectation and reality as a commitment which is set before, and 3 quality and integrity are inseparable".

Customer satisfaction is very important to determine the success of the implementation of quality services. Customer satisfaction can be achieved if there is conformity between what is expected by the customer with the reality obtained, in this case, is the quality of a product in such as goods or services, Supranto [14] stated that "a product has quality if it can meet their needs".

Sugiarto [15] stated that the measurement of the success of service is not measured by the management but by service users. Then, it is used to build a modern service quality system to be effective. Gaspersz in Lukman [13] formulated 13 steps to take. Those are as follows:

a. Define and specify the objectives and wisdom of quality.

b. customer satisfaction oriented.

c. Direct all activities to achieve the goals and policies of quality that have been established.

d. Integrate the activities within the organization.

e. Provide explanations and duties to workers that should be concerned with the quality of goods or services to do an integrated quality control program.

f. Specify the quality control to the seller.

g. Identify the quality of the equipment carefully.

h. Identify and streamline the flow of quality information, process it and control it.

i. Conduct training and motivate employees to continue to work with the orientation to improve quality.

j. Control the cost of quality and other measurements and set the quality standards.

k. Make the corrective action that has a positive impact.

1. Continue the control system which covers the next step, receive feedback information, analyze the result, and compare with quality standard.

m. Check activities of the modern quality system periodically

Those steps above illustrate that no matter what the circumstances are,

The above steps illustrate that whatever the form is, the circumstance is, there is no reason for the service provider not to satisfy the customer. The expectation of customer get the first place because it determines the existence of the organization itself, so it needs a strong commitment to realizing the mission of excellent service.

In addition, Zethaml in Sedarmayanti [16] stated that the measurement of service quality can be measured by ten dimensions. Those are:

a. Tangibles, it consists of physical facilities, equipment, personnel, and communications.

b. Reliability, it consists of the ability of service units in creating a service which is promised.

c. Responsiveness, the ability to make the customer responsible for the quality of service provided.

d. Competence, it is a must for the apparatus giving the service to have good knowledge and skill.

e. Courtesy, friendly attitude or behavior, responsive to the needs of consumers, and want to make contact or personal relationships. 
f. Credibility, honest attitude in every effort to attract public trust.

g. Security, the services provided must be free from various dangers and risks.

h. Access, it is easy to get contact or approach.

i. Communication, willingness to provide services to listen to the voice, desire or aspirations of customers, as well as the willingness to always convey new information to society.

j. Understanding the Customer, it makes every effort to know customer needs.

In practical operation, the quality service of government to society is the better service, the more timely, the easier to obtain, and the distribution is fair, faster service, reasonable, efficient, cheap, honest, responsive accommodative, innovative, productive, satisfying and professional. Thoha, Pamungkas, Rashid, Ndraha [17], as the perceptions, demands, needs, interests, aspirations, circumstances and conditions of society. It should be understood that general service is a duty that must be done by the government apparatus to achieve general satisfaction.

Employees in an organization or office in work must have high motivation. Employees can actualize themselves with the ability they have to take a role in the organization. The motivation that needs to be developed within the organization is the motivation of work. According to Siagian motivation is "the whole business, ways, techniques, and methods that encourage the members of the organization to work consciously in order to achieve organizational goals efficiently, effectively and economically".

Employee motivation will arise when the needs of employees are met. Therefore, to encourage the employee working well, it needs to pay attention and meet the various needs of employees.

Mc. Clelland in Hasibuan put forward his theory of Mc Clelland's Achievement Motivation Theory. The things that motivate employees are:

a. Need for Achievement, 2 Need for Affiliation, 3Need for Power. The explanations are as follows:

1) The Need for achievement

2) The need for achievement is a trigger that motivates people's spirit to work because this need will encourage someone to develop their creativities and aim all skills and energies to achieve the job performance. The employees will be enthusiastic to work well if they are given the opportunity. The need for achievement reflects their desire to take responsibility for doing a job given. They decide the goals and also count the risk from the job. They get feedback from their attire and they try to do everything with creative and innovative. They realize that they will get high income if they work well. By the high income, they can fill their needs.

3) The need for affiliation

This is shown by the desire to associate where they emphasize on their work, they are happy to cooperate, they ask other opinions to get the agreement form the others, and they do their job more effective if they cooperate with others in cooperation. Thus, this need attracts the spirit of employees to work because everyone wants things as follows:

4) Sense of belonging, 2 Sense of important, 3 Sense of achievement, 4 Sense of participation

5) The need for power

The need for power is a trigger that motivates people's spirit to work. This need reflects on someone who has influence over others, sensitivity to influence structure among groups or organizations, entering the organization that has the achievement, obeying the policy of the organization, trying to lead others by managing them and make them impressed and keeping the reputation and leadership. Thus, this need will attract and 
motivate the spirit of employees to work and they are all out with their capabilities in order to achieve the power and good position.

Another factor that also affects job satisfaction is the discipline of work. The institution makes rules which all employees obey and implement essentially with the purpose that all employees can work well with their competencies.

Discipline is an attitude of obedience to a rule or provisions that are applied in the organization on the basis of the existence of awareness and conviction, not coercion. Heidjrachman and Husnan [3] stated that discipline is every individual and group that ensures compliance of the command and has initiative to do an action required if there is no command ". According to Davis "discipline is a management action to encourage the implementation of organizational standards. This is the training that leads to efforts to justify and involve knowledge of attitudes and behaviors of employees so there is a willingness in the employee to cooperate and achieve better performance". Discipline is also defined as a willingness of someone that arises consciously to obey the rules in the organization.

According to Lateiner in Imam Soejono generally, employee discipline can be measured by:

a. The employees come to the office orderly, and on time. By coming to the office orderly, and on time, so discipline of work is good.

b. Dressing neatly

Dressing neatly is one of the factors that influence employees discipline, because dressing neatly will feel more comfortable and confidence.

c. Using the office facilities carefully

Careful attitude can indicate that a person has a good working discipline because if the employees use the office facilities carelessly, the damage will happpen and it becomes disadvantages.

d. Following the procedures of work set by the organization

By following the procedures of work set by the organization, it can indicate that the employees have a good working discipline and obey the rules of the organization.

e. Having a responsibility

Responsibility has a big influential on the discipline of work. With the responsibility to the jobs, it can show that the discipline of employees is good.

\subsection{Effect of Motivation on Service Quality}

According to Mc. Clelland's theory, individuals have a potential energy reserve. How energy is released and used depends on the strength of someone, situation, and available opportunities. Energy will be used by individual with the encouragement, such as 1 the power of motive and the basic power that involved, 2 the expectation of success, and 3 the incentive value in the goals. Things that motivate someone is:

a. The Need for achievement: the needs for achievement innovative and creative indicators, feedback on achievement, choosing risks in work and having responsibility for achievement.

b. The Need for Affiliation: the needs for affiliation include cooperative indicators, maintaining social relationships, helping co-workers, and avoiding conflict.

c. The Need for Power: the needs for power include an indicator of the ability to speak in public, active in determining the direction of the organization, to feel pleased to be appointed as the leader of the organization, to feel happy to teach the knowledge to others. 


\section{Conclusion}

Motivation has a positive and significant impact on service quality, the better the motivation the better the quality of service. so that motivation has a real effect to improve the quality of service.

The discipline of employees has a positive and significant impact on the quality of service, for example, the better the discipline of employees the better the quality of service so the discipline of employees has a real effect to improve the quality of service.

\section{References}

[1] J. W. Cresswell, Research Design. Pendekatan Kualitatif, Kuantitatif, dan Mixed. Yogyakarta: Pustaka Pelajar, 2014.

[2] S. P. Siagian, Organisasi, Kepemimpinan dan Perilaku Administrasi. Jakarta: Haji Masagung, 1999.

[3] H.- Husnan, Manajemen Personalia. Yogyakarta: BPFE, 2002.

[4] H. M. S.P, Organisasi dan Motivasi. Jakarta: PT. Bumi Aksara, 2005.

[5] G. T. Liang, Administrasi Perkantoran Modern. Yogyakarta: Nur Cahaya, 1982.

[6] Wursanto, Manajemen Kepegawaian. Yogyakarta: Kanisius, 1987.

[7] R. Terr George, Pengembangan Sumber Daya Manusia. Yogyakarta: Liberty, 1993.

[8] Priyono, Manajemen Sumber Daya Manusia, no. April. Jakarta: Ghalia Indonesia, 2005.

[9] W. Joko, Good Governance Telaah dari Dimensi Akuntabilitas dan Kontrol Birokrasi Pada Era Desentralisasi dan Otonomi Daerah. Surabaya: Insan Cendekia, 2001.

[10] K. Philip, Manajemen Pemasaran di Indonesia: Analisis Perencanaan Implementasi dan Pengendalian. Jakarta: Salemba Empat, 2002.

[11] F. Tjiptono and A. Diana, Total Quality Management. Yogyakarta: Andi, 2001.

[12] A. S. Moenir, Manajemen Pelayanan Umum di Indonesia. Jakarta: PT.Bumi Aksara, 2006.

[13] S. Lukman, Manajemen Kualitas Pelayanan. Jakarta: STIA LAN Press, 2000.

[14] J. Supranto, Pengukuran Tingkat Kepuasan Pelanggan. Jakarta: RINEKA CIPTA, 2001.

[15] S. Endar, Psikologi Pelayanan Dalam Industri Jasa. Jakarta: PT. GaramediaPustaka Utama, 1999.

[16] A. Moenir, Manajemen Pelayanan Umum di Indonesia. Jakarta: Sedarmayanti, 2009.

[17] Thoha, Birokrasi Pemerintah dan Kekuasaan di Indonesia. Yogyakarta: Thafa Media, 2012. 
